\title{
血漿 $\alpha_{2}$ プラスミン・インヒビターープラスミン複合体 $\left(\alpha_{2}\right.$ PIPC) 測定による糖尿病性腎症患者に おける線溶状態の評価
}

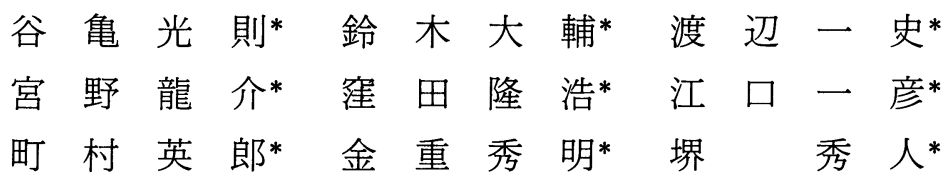

Fibrinolysis in Patients with Diabetic Nephropathy Evaluated by Plasma Levels of $\alpha_{2}$ Plasmin Inhibitor-plasmin Complexes

\author{
Mitsunori YAGAME*, Daisuke SUZUKI*, Kazufumi WATANABE*, \\ Ryusuke MIYANO*, Takahiro KUBOTA*, Kazuhiko EGUCHI*, \\ Hideo MACHIMURA*, Hideaki KANESHIGE*, Hideto SAKAI*
}

Key words : diabetic nephropathy, proteinuria, $\alpha_{2}$ PIPC, fibrinolysis

Activation of fibrinolysis in patients with diabetic nephropathy was determined by the plasma levels of $\alpha_{2}$ plasmin inhibitor-plasmin complexes ( $\alpha_{2}$ PIPC). The levels of $\alpha_{2}$ PIPC in plasma were measured by the one-step sandwich enzyme immunoassay (EIA). This quantitative assay of $\alpha_{2}$ PIPC could be valuable for the assessment of fibrinolysis. Plasma levels of $\alpha_{2}$ PIPC in diabetic patients with overt proteinuria were significantly higher than those in diabetic patients without proteinuria or in chronic glomerulonephritis patients with proteinuria ( $\mathrm{P}<0.01$, respectively). Plasma levels of $\alpha_{2}$ PIPC in diabetic patients with intermittent proteinuria were also significantly higher than those in diabetic patients without proteinuria or in chronic glomerulonephritis patients with proteinuria $(\mathrm{P}<0.05$, respectively). These findings indicated that the activation of fibrinolysis as well as the coagulation system might play a role in the development and/or progression of diabetic nephropathy.

\footnotetext{
* 東海大学医学部内科学第七教室〔̄ 259-11 神奈川県伊勢原市望星台〕; Division of Metabolism and Nephrology, Department of Internal Medicine, School of Medicine, Tokai University, Bohseidai, Isehara City, Kanagawa, 259-11, Japan. 受付 1989.10.23, 受理 1990.3.10.
} 


\section{緒言}

血漿 $\alpha_{2}$ プラスミンインヒビター $\left(\alpha_{2} \mathrm{PI}\right)$ は 生体内の線維素溶解機構（線溶系）に対する特 異的な調節能を持ち，プラスミンと即時的，不 可逆的に結合して止血栓の維持と溶解の調節に 重要な役割を果たしている。この $\alpha_{2} \mathrm{PI}$ とプラ スミンが結合して生じるのが血漿 $\alpha_{2}$ プラスミ ンインヒビター-プラスミン複合体 $\left(\alpha_{2} \mathrm{PIPC}:\right.$ 以下 PIPC と略す) であり，これはプラスミノ ーゲンの活性化によるプラスミンの産生を鋭敏 に反映しており，各種線溶穴進，特に沉発性血 管内凝固症候群 (DIC) および DIC 準備状態の 診断や治療効果の判定，血栓溶解療法および線 溶療法での線溶状態のモニタリングに極めて有 用であるとされている1). PIPC の測定法とし て, 最近, 酵素免疫法が開発され, 各種病態の 凝固線溶系についての，様々な報告がなされて (る ${ }^{1) \sim 3)}$.

糖尿病性腎症は，糖尿病合併症の中では生命 予後に最も影響を及ぼす重要な合併症である。 血糖や感染のコントロールがなされ糖尿病患者 の長期生存が可能となった現在でも，糖尿病性 腎症の治療は困難であり透析患者も増加してき ている4)。このような糖尿病性腎症をはじめと する細小血管合併症の発症や進展に凝固線溶系 が関与しているとされており ${ }^{577)}$, 今回糖尿病 性腎症の臨床的指標である蛋白尿の程度と血漿 PIPC 值について検討し，若干の知見を得たの で報告する。

\section{対象と方法}

\section{（1）患者}

対象とした患者は, 東海大学病院内科学第七 教室外来通院中の 44 名（男 28 名, 女 16 名) のインスリン非依存性糖尿病（NIDDM：noninsulin dependent diabetes mellitus) 患者であ る. 全症例の平均年齢は 54.0 歳であり, 肝機 能障害や血液凝固異常を呈する患者は対象から 除外した。一月に一回の尿検査において，6力 月以上試験紙法で蛋白尿のみられない 21 名 (男 12 名, 女 9 名: 年齢 $32 \sim 68$ 歳, 平均 $54.9 \pm 8.7$ 歳）をグループ A, 間欠的に蛋白尿
のみられる 9 名 (男 6 名, 女 3 名: 年 齢 $39 \sim 64$ 歳, 平均 $50.9 \pm 8.7$ 歳）をグループ B, 持続して蛋白尿のみられる 14 名（男 10 名, 女 4 名：年齢 $31 \sim 80$ 歳, 平均 $54.6 \pm 12.8$ 歳）を グループ C とした。なお間欠的蛋白尿とは， 6 回の尿検査中 $1 \sim 2$ 回に尿蛋白が士〜+を示し たものとした。

また，持続的に蛋白尿を呈し，汃糖尿病を 合併していない慢性系球体腎炎患者 (以下糸球 体腎炎群と略す) 15 名（男 9 名, 女 6 名: 年 齢 20〜63 歳, 平均 42.4 13.4 歳）を対照とし た。これらの原疾患の内訳は, IgA 腎症 9 名, 良性腎硬化症 3 名, 膜性腎症 1 名, 膜性増殖性 系球体腎炎 1 名, 半月体形成性腎炎 1 名であっ た。

\section{(2) 血漿 PIPC の測定}

血漿 PIPC の測定は，モノクローナル抗体を 用いた one-step sandwich enzyme immunoassay（EIA）(帝人) で行った。まず， $10 \mu l$ の血 漿を生食塩水で $8 \mathrm{~m} l$ (800 倍希釈) としたもの を $200 \mu l$ と, PIPC 標準液 (10，20，40 $\mu \mathrm{g} /$ $\mathrm{m} l) 200 \mu l$ を各々試験管に採取する。ついで,

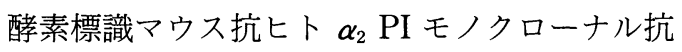
体液を各試験管に $200 \mu l$ 加え, ウサギ抗ヒト プラスミノーゲン抗体を固定した polystyrene ball を各試験管に加える. $37^{\circ} \mathrm{C}$ の恒温槽中で 1 時間反応させた後, 生理食塩水で 3 回洗浄し発 色剂 $(0.05 \%$ ABTS 含有 $0.1 \mathrm{M}$ リン酸クエン 酸緩衝液） $400 \mu l$ を各試験管に加える。さ に, $37^{\circ} \mathrm{C}$ の恒温槽中で 30 分間反応させた後, 反応停止液として $0.25 \mathrm{M}$ シュウ酸を $1 \mathrm{~m} l$ 加 え， $420 \mathrm{~nm}$ の波長で吸光度を測定する。なお 測定範囲は $0.3 \sim 40 \mu \mathrm{g} / \mathrm{m} l$ であるが，測定感 度以下の場合は, 統計学的計算上 $0.2 \mu \mathrm{g} / \mathrm{m} l$ として処理した。帝人での血漿 PIPC の参考正 常值は, $0.8 \mu \mathrm{g} / \mathrm{m} l$ 以下である.

\section{（3）臨床指標の検討}

糖尿病患者に対しては，血漿 PIPC の測定時 に下記の各項目について検索した。すなわち， 糖尿病罹病期間, 高血圧の有無, 尿蛋白定性 ・ 定量（定量はグループ C のみ），尿糖，尿潜血 反応，へモグロビン $\mathrm{A} 1 \mathrm{c}$, 空腹時血糖, 血清 クレアチニン，総蛋白，アルブミン，総コレス 


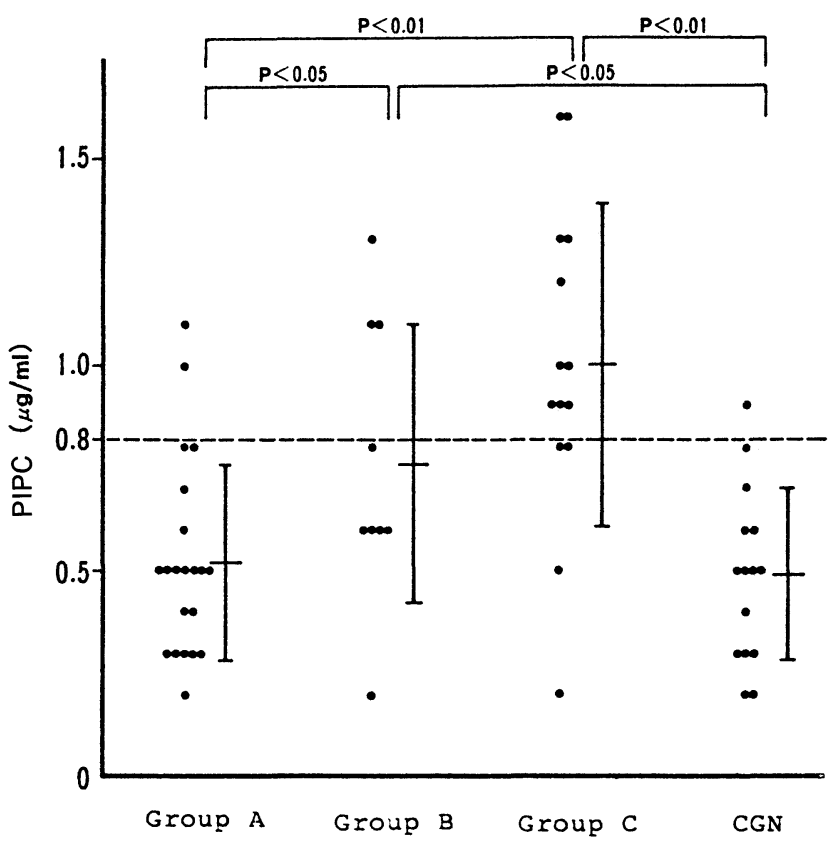

Fig. 1 Plasma levels of PIPC among four groups of patients (CGN : chronic glomerulonephritis)
Table 1 Clinical parameters and their evaluation

\begin{tabular}{|c|c|c|}
\hline Clinical parameters & $\begin{array}{l}\text { Abbrevia- } \\
\text { tion }\end{array}$ & Evaluation \\
\hline Duration of diabetes & DUR & years \\
\hline Hypertension & $\mathrm{HT}$ & $\begin{array}{l}\text { more than } \\
140 / 90 \mathrm{mmHg}\end{array}$ \\
\hline $\begin{array}{l}\text { Proteinuria } \\
\text { degree }\end{array}$ & PRO & $\begin{array}{l}-: 1, \pm: 2,+: 3 \\
++: 4,+++: 5\end{array}$ \\
\hline amounts & UP & g/day \\
\hline Glucosuria & GLU & $\begin{array}{l}-: 1, \pm: 2,+: 3 \\
++: 4,+++: 5\end{array}$ \\
\hline Hematuria & HEM & $\begin{array}{l}-: 1, \pm: 2,+: 3 \\
++: 4,+++: 5\end{array}$ \\
\hline Hemoglobin Alc & $\mathrm{HBA}$ & $\%$ \\
\hline Fasting blood sugar & FBS & $\mathrm{mg} / \mathrm{d} l$ \\
\hline Serum creatinine & $\mathrm{CR}$ & $\mathrm{mg} / \mathrm{d} l$ \\
\hline Total protein & $\mathrm{TP}$ & $\mathrm{g} / \mathrm{d} l$ \\
\hline Serum albumin & ALB & $\mathrm{g} / \mathrm{d} l$ \\
\hline Total cholesterol & $\mathrm{TC}$ & $\mathrm{mg} / \mathrm{d} l$ \\
\hline Triglyceride & TG & $\mathrm{mg} / \mathrm{d} l$ \\
\hline Hemoglobin & $\mathrm{HGB}$ & $\mathrm{g} / \mathrm{d} l$ \\
\hline Platelets & PLT & $\times 10^{4} / \mu l$ \\
\hline Prothrombin time & $\mathrm{PT}$ & $\begin{array}{l}\text { sec. (control : } \\
10.6 \mathrm{sec})\end{array}$ \\
\hline $\begin{array}{l}\text { Partial thromboplas- } \\
\text { tin time }\end{array}$ & PTT & $\begin{array}{l}\text { sec. (control: } \\
32.4 \mathrm{sec} \text { ) }\end{array}$ \\
\hline Fibrinogen & FIB & $\mathrm{mg} / \mathrm{d} l$ \\
\hline
\end{tabular}

テロール，中性脂肪，へモグロビン，血小板， プロトロンビン時間, 部分トロンボプラスチン 時間，フィブリノーゲンである。この内，尿蛋 白定性, 尿糖, 尿潜血反応の 3 項目について は, 統計学的処理の可能なように数量化を行っ た (Table 1).

\section{(4) 統計学的検討}

統計学的検討は, $\mathrm{t}$ 検定, 単純相関分析, $\chi^{2}$ 検定にて行った。

\section{結 果}

\section{（1）血漿 PIPC の測定}

正常值以上 $(0.9 \mu \mathrm{g} / \mathrm{m} l$ 以上) の高值を示 した症例は,グループ A では 21 例中 2 例 $(9.5 \%)$ ，グループ B では 9 例中 3 例 $(33.3 \%)$ ，グループ C では 14 例中 10 例 $(71.4 \%)$, 系球体腎炎群では 15 例中 1 例 (6.7\%) であり，グループCでは PIPC が正常 值以上を示す割合は，グループ A および糸球 体腎炎群のそれと比較して，有意に高率であっ た（各々 $x^{2}=14.2874, \mathrm{P}<0.01 ; x^{2}=$

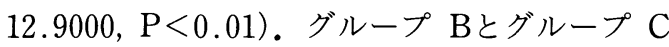
の PIPC 值はそれぞれ $0.76 \pm 0.34 \mu \mathrm{g} / \mathrm{m} l$ (平 
Table 2 Clinical parameters and statistical significance among for groups of patients

\begin{tabular}{|c|c|c|c|c|c|c|c|}
\hline & \multirow{2}{*}{$\begin{array}{c}\text { Group A } \\
\text { (without } \\
\text { proteinuria) }\end{array}$} & \multirow{2}{*}{$\begin{array}{c}\text { Group B } \\
\text { (intermittent } \\
\text { proteinuria) }\end{array}$} & \multirow{2}{*}{$\begin{array}{c}\text { Group C } \\
\text { (overt } \\
\text { proteinuria) }\end{array}$} & \multicolumn{3}{|c|}{ statistical significance } & \multirow{2}{*}{$\begin{array}{l}\text { Chronic } \\
\text { glomerulo- } \\
\text { nephritis }\end{array}$} \\
\hline & & & & $A$ vs $B$ & $\mathrm{~B}$ vs $\mathrm{C}$ & $A$ vs $C$ & \\
\hline DUR & $7.86 \pm 5.76$ & $8.56 \pm 7.65$ & $13.0 \pm 7.96$ & N.S. & N.S. & $\mathrm{P}<0.05$ & 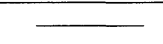 \\
\hline $\mathrm{HT}$ & $42.9 \%(9 / 21)$ & $55.6 \%(5 / 9)$ & $71.4 \%(10 / 14)$ & N.S. & N.S. & N.S. & $53.3 \%(8 / 15)$ \\
\hline PRO & $1.00 \pm 0.00$ & $1.56 \pm 0.53$ & $4.50 \pm 0.65$ & $\mathrm{P}<0.05$ & $\mathrm{P}<0.01$ & $\mathrm{P}<0.01$ & $3.53 \pm 1.80$ \\
\hline UP & & - & $3.29 \pm 3.81$ & & & $\longrightarrow$ & $1.98 \pm 1.98$ \\
\hline GLU & $1.90 \pm 1.41$ & $2.33 \pm 1.50$ & $2.29 \pm 1.59$ & N.S. & N.S. & N.S. & $1.07 \pm 0.26$ \\
\hline HEM & $1.05 \pm 0.22$ & $1.33 \pm 0.71$ & $1.71 \pm 0.73$ & N.S. & N.S. & $\mathrm{P}<0.01$ & $2.67 \pm 1.40$ \\
\hline $\mathrm{HBA}$ & $8.57 \pm 1.22$ & $9.03 \pm 1.49$ & $8.31 \pm 1.43$ & N.S. & N.S. & S.S. & \\
\hline FBS & $142.3 \pm 45.7$ & $179.8 \pm 55.3$ & $147.2 \pm 47.6$ & N.S. & N.S. & N.S. & $96.0 \pm 25.2$ \\
\hline $\mathrm{CR}$ & $0.79 \pm 0.18$ & $0.78 \pm 0.10$ & $1.88 \pm 1.67$ & N.S. & $\mathrm{P}<0.05$ & $\mathrm{P}<0.05$ & $1.08 \pm 0.46$ \\
\hline $\mathrm{TP}$ & $6.94 \pm 0.55$ & $7.12 \pm 0.40$ & $6.10 \pm 0.79$ & N.S. & $\mathrm{P}<0.01$ & $\mathrm{P}<0.01$ & $6.15 \pm 0.79$ \\
\hline ALB & $4.23 \pm 0.32$ & $4.36 \pm 0.34$ & $3.75 \pm 0.54$ & N.S. & $\mathrm{P}<0.01$ & $\mathrm{P}<0.01$ & $3.81 \pm 0.43$ \\
\hline $\mathrm{TC}$ & $193.4 \pm 32.4$ & $220.8 \pm 36.2$ & $226.6 \pm 68.1$ & $\mathrm{P}<0.05$ & N.S. & N.S. & $181.3 \pm 50.7$ \\
\hline TG & $180.1 \pm 183.9$ & $142.3 \pm 55.0$ & $216.1 \pm 115.0$ & N.S. & N.S. & N.S. & $154.1 \pm 124.7$ \\
\hline $\mathrm{HGB}$ & $13.48 \pm 1.68$ & $13.46 \pm 1.66$ & $12.24 \pm 2.25$ & N.S. & N.S. & N.S. & $13.09 \pm 1.26$ \\
\hline PLT & $23.28 \pm 5.08$ & $26.02 \pm 5.72$ & $25.70 \pm 4.48$ & N.S. & N.S. & N.S. & $23.25 \pm 4.75$ \\
\hline PT & $10.44 \pm 0.43$ & $9.87 \pm 0.37$ & $10.16 \pm 0.43$ & $\mathrm{P}<0.01$ & N.S. & N.S. & $10.58 \pm 0.73$ \\
\hline PTT & $30.51 \pm 2.56$ & $28.54 \pm 3.48$ & $31.08 \pm 2.70$ & N.S. & N.S. & N.S. & $32.10 \pm 3.29$ \\
\hline FIB & $258.4 \pm 45.8$ & $280.6 \pm 50.4$ & $312.7 \pm 82.1$ & N.S. & N.S. & $\mathrm{P}<0.05$ & $241.8 \pm 43.7$ \\
\hline
\end{tabular}

mean \pm ISD, N.S.: not significant

Table 3 Correlation between the plasma levels of PIPC and other clinical parameters

\begin{tabular}{lrc}
\hline $\begin{array}{c}\text { Clinical } \\
\text { Parameters }\end{array}$ & r value & $\begin{array}{c}\text { Statistical } \\
\text { significance }\end{array}$ \\
\hline DUR & 0.2613 & N.S. \\
HT & 0.0963 & N.S. \\
PRO & 0.5330 & $\mathrm{P}<0.01$ \\
GLU & -0.2520 & N.S. \\
HEM & 0.3895 & $\mathrm{P}<0.05$ \\
HBA & -0.1890 & N.S. \\
FBS & -0.3217 & $\mathrm{P}<0.05$ \\
CR & 0.3439 & $\mathrm{P}<0.05$ \\
TP & -0.3535 & $\mathrm{P}<0.05$ \\
ALB & -0.5639 & $\mathrm{P}<0.01$ \\
TC & -0.0527 & N.S. \\
TG & -0.1479 & N.S. \\
HGB & -0.4337 & $\mathrm{P}<0.01$ \\
PLT & 0.2113 & N.S. \\
PT & -0.1008 & N.S. \\
PTT & 0.1776 & N.S. \\
FIB & 0.1410 & N.S. \\
\hline
\end{tabular}

N.S.: not significant

均 $\pm \mathrm{SD}), 1.00 \pm 0.39 \mu \mathrm{g} / \mathrm{ml}$ であり,グルー プ A の $0.52 \pm 0.24 \mu \mathrm{g} / \mathrm{m} l$ に比べ有意に高値 を示した（各々， $\mathrm{P}<0.05, \mathrm{P}<0.01)$. また系 球体腎炎群の PIPC 值は $0.49 \pm 0.21 \mu \mathrm{g} / \mathrm{m} l$ で あり,グループ B やグループ C と比べ, 有意
に低值を示した（各々， $\mathrm{P}<0.05, \mathrm{P}<0.01)$ (Fig. 1).

\section{（2）他の臨床検查成績}

グループ A とグループ B の間には，蛋白尿 定性, 総コレステロール，プロトロンビン時間 の各項目において，統計学的有意差が認められ た（各々，P<0.05, P<0.05, $\mathrm{P}<0.01) . ま$ た，グループ B とグループ C の間には，蛋白 尿定性, 血清クレアチニン, 総蛋白, 血清アル ブミンの各項目において, 統計学的有意差が認 められた（各々， $\mathrm{P}<0.01, \mathrm{P}<0.05, \mathrm{P}<0.01$, $\mathrm{P}<0.01)$.さらに, グループ $\mathrm{A}$ とグループ C の間には, 罹病期間, 蛋白尿定性, 尿潜血反 応, 血清クレアチニン, 総蛋白, 血清アルブミ ン, フィブリノーゲンの各項目において, 統計 学的有意差が認められた（各々, $\mathrm{P}<0.05, \mathrm{P}<$ $0.01, \mathrm{P}<0.01, \mathrm{P}<0.05, \mathrm{P}<0.01, \mathrm{P}<0.01, \mathrm{P}<$ 0.05) (Table 2).

\section{（3）血墏 PIPC と他の臨床検査成績}

全症例の血漿 PIPC 值と他の各項目との相関 関係を示したものがTable 3 である。血漿 PIPC 值は，尿蛋白定性，尿潜血反応，血清ク レアチニンと有意な正の相関が認められた （各々， $\mathrm{P}<0.01, \mathrm{P}<0.05, \mathrm{P}<0.05)$.また，同 様に, 空腹時血糖, 総蛋白, 血清アルブミン, 
へモグロビンと有意な負の相関が認められた (各々, $\mathrm{P}<0.05, \mathrm{P}<0.05, \mathrm{P}<0.01, \mathrm{P}<0.01$ ) (Table 3).

\section{考察}

線溶系の中心的役割を担うプラスミンを直接 測定することは，現在では不可能であるが，プ ラスミンと $\alpha_{2}$ プラスミン・インヒビター $\left(\alpha_{2}\right.$ PI）との複合体である血漿 PIPC は測定可能で

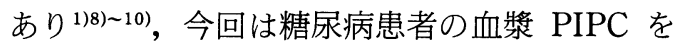
one-step sandwich EIA ${ }^{1)}$ を用いて測定し検討 した。この PIPC は, 生体内で線溶系の活性化 の鋭敏な指標になりうると考えられているが, 今回の検討では，PIPC は糖尿病性腎症患者に おいて高值を示した.

抗 $\alpha_{2} \mathrm{PI}$ モノクローナル抗体 ${ }^{11)}$ を用いた本法 は, PIPC を定量的に測定可能であり, その測 定範囲も $0.3 \sim 40 \mu \mathrm{g} / \mathrm{m} l$ と非常に広く，また わずか $10 \mu l$ の血漿で測定できるなどの特長を 持っている。ささらに，プラスミノーゲンや $\alpha_{2}$ PI などの類似蛋白や乳び，ビリルビン，へモ グロビンの影響を受けずに特異性が高いことも 特長の一つである。

従来, 糖尿病患者では, 血液凝固艺進と線溶 活性の低下が認められるとする報告が多( ${ }^{5) ~ 7) ~}$ が，PIPC を測定しての線溶状態の評価をして いる報告は見られていない，今回の検討では， 糖尿病性腎症の臨床的特徵とされている蛋白尿 を持続的に示す糖尿病患者，あるいは間欠的に 蛋白尿を示す糖尿病患者では，蛋白尿を示さな い糖尿病患者および持続的蛋白尿を呈する慢性 糸球体腎炎患者より，PIPC 值が高い傾向が認 められた。なお糖尿病患者の各グループ間の平 均年齢に有意差はなく, aging の影響はないも のと考えられる。また，尿所見異常のない健常 人の血漿 PIPC は，男性では $0.19 \pm 0.15 \mu \mathrm{g} /$ $\mathrm{m} l$ (平均 $\pm \mathrm{SD}, \mathrm{n}=25)$ ，女性では $0.35 \pm 0.23$ $\mu \mathrm{g} / \mathrm{m} l \quad(\mathrm{n}=50)$ と報告されている ${ }^{10)}$. 蛋白尿 を示さない糖尿病患者でさえも，これら尿所見 異常のない健常人と比較すると, PIPC 值は統 計学的に有意に高值を示す $(\mathrm{P}<0.01)$ ことか ら, 糖尿病患者では臨床的に蛋白尿のみられな い比較的早期から線溶系の活性化が生じてお
り，蛋白尿の出現とともにさらに線溶活性が増 すことが示唆される。この線溶系の活性化は, 従来の報告を考えると, 糖尿病患者では元来血 液凝固能が亢進しており，それに対し結果的に 線溶系の活性化が生じたものと推測される。

各グループ間の比較では, グループ A とグ ループ C の間に, 罹病期間と血尿で有意差が みられている，罹病期間が長くなるにつれて糖 尿病性腎症の有病率が高くなることは，広く知 られているが，血尿については不明である。し かし，腎生検を施行していないため，グループ Cには糖尿病患者に慢性系球体腎炎が偶然合併 した症例も含まれていることが考えられ，有意 差の出現した原因の一つと思われる，血清クレ アチニン, 総蛋白, アルブミン值は, 腎症の進 行あるいは蛋白尿の増加とともに変化するの で，各グループ間に有意差があることが容易に 理解される。また，グループ A, B , C の順に, フィブリノーゲンが上昇し，特にグループ $\mathrm{A}$ とグループ C の間には，有意差が存在するが, これは梅津ら ${ }^{6)}$ の報告と一致し，グループ C ではグループ A よりも血液凝固能が亢進して いることが示唆される。

全症例での血漿 PIPC と各検查項目との比較 では，いくつかの項目と正相関あるいは逆相関 を示している，とくに，PIPC と空腹時血糖值 とが逆相関を示したことは注目すべきことであ るが，PIPC とへモグロビン Alc とは有意な 相関は認められなかった。このことから，長期 ではなく短期の血糖コントロールと PIPC は何 か関連があることが示唆されるが，測定法に影 響を与えていることは考えにくく，明らかな意 義は見出だせない.

梅津ら ${ }^{6)}$ は，糖尿病性腎症では，血液凝固六 進が特に腎局所でみられるため，血漿より尿中 の凝固関連物質の測定が重要であると報告して いる．このことから考えると，線溶活性の評価 には，血漿のみならず尿中 PIPC の測定も重要 であると考えられる。

今回は, 糖尿病患者の血漿 PIPC 值と糖尿病 性腎症の臨床的特徵である蛋白尿との関係を報 告した。糖尿病患者の血液凝固線溶系は，腎症 をはじめとする細小血管合併症の発症・進展に 
重要な役割を担っていると考えられ，その解明 は, 今後の研究課題の一つである.

\section{参考文献}

1）青木延雄, 武永 強, 長谷川淳, 小熊 豊, 小林紀夫, 坂田洋一, 藤巻道男, 池松正次郎, 緇茌和子, 松田 保, 伊藤恵子, 藤原研司, 富谷智明, 林 茂樹, 中村克 己, 飯島憲司, 觜見芳彦, 小池行也, 鈴木英明, 細田健 治: EIA 法による $\alpha_{2}$ PI (TD-80) および $\alpha_{2}$ PI プラ スミン複合体（TD-80C）測定キットの基礎的研究. 臨床病理 $35:$ 1275 1281, 1987.

2) 福田千左子, 飯島憲司, 井上信正, 高島義顕, 渡辺千 晶, 中村克己：EIA 法による $\alpha_{2}$ プラスミンインヒ ビターおよび $\alpha_{2}$ プラスミンインヒビターープラス ミン複合体動態の臨床的意義一主として災害外科 領域から一. 臨床病理 $36:$ 346〜350, 1988.

3）飯島憲司: 活性化凝固・線溶系因子一阻止物質との 複合体一. 臨床病理 $36: 623 \sim 626,1988$.

4）小高通夫：透析患者の予後と死因. 日本臨床（特別 号) $43: 481,1985$.

5）永川祐三, 折茂 肇, 原沢道美, 沢田皓史：動脈硬化 症および糖尿病における血小板凝集能, $\beta$-トロンボ グロブリン, アポ蛋白, アンチトロンビン III, 線 溶に関する研究. 日本老年医学会雑誌 $22 ： 13 \sim 19$, 1985.

6）海津嘉蔵, 森田恵美子, 瓜生康平, 竹内昭彦, 伊藤幸
郎, 江藤澄哉, 鈴木秀郎: 糖尿病における凝固・線溶 系一特に, 糖尿病性腎症を中心として一. 血液と脈 管 17 : 362 364, 1986.

7) Geiger $M$ and Binder BR.: Nonenzymatic glucosylation as a contributing factor to defective fibrinolysis in diabetes mellitus. Haemostasis 16 : 439 446, 1986.

8) Harpel PC.: $\alpha_{2}$-plasmin inhibitor and $\alpha_{2}$ macroglobulin-plasmin complexes in plasma; Quantitation by an enzyme-linked differential antibody immunosorbent assay. J. Clin. Invest. 68: 46〜55, 1981.

9) Holvoet P, de Boer A, Versteken M and Collen D. : An enzyme-linked immunosorbent assay (ELISA) for the measurement of plasmin- $\alpha_{2}$ anti-plasmin complex in human plasma; Application to the detection of in vivo activation of the fibrinolytic system. Thromb. Haemost. 56 : 124 127, 1986.

10）緇荘和子, 赤尾昌文, 山元泰之, 池松正次郎, 藤巻道 男 : $\alpha_{2}$ 一プラスミンインヒビター・プラスミン複合 体の測定について. 機器・試薬 $10: 1075 \sim 1079,1987$.

11) Mimuro J, Koike $Y$, Sumi $Y$ and Aoki N.: Monoclonal antibodies to discrete regions in $\alpha_{2}$-plasmin inhibitor. Blood 69 : 446 453, 1987. 